\title{
Trichomycterus dali: a new highly troglomorphic catfish (Silurifomes: Trichomycteridae) from Serra da Bodoquena, Mato Grosso do Sul State, Central Brazil
}

\author{
Pedro Pereira Rizzato ${ }^{1}$, Edmundo P. D. Costa-Jr. ${ }^{2}$, Eleonora Trajano ${ }^{3}$ and \\ Maria Elina Bichuette ${ }^{1}$
}

Trichomycterus dali, new species, is described from flooded limestone caves in Serra da Bodoquena karst area, State of Mato Grosso do Sul, Central Brazil. The new species is diagnosed by a unique character in the genus, the presence of conspicuous, ridge-like adipose folds lining dorsally throughout the body. Trichomycterus dali can be further distinguished readily from epigean congeners by the reduction of eyes and skin pigmentation (except for $T$. gorgona), and from remaining congeners (i.e., all hypogean plus T. gorgona) by the total loss of eyes, not visible externally (except for T. sandovali and T. spelaeus). Other diagnostic features includes very long barbels, especially the nasal (99.3-143.5\% HL) and the maxillary (97.0-131.3\% HL), pectoral-fin ray count reaching I,9 and a unique cranial fontanel with a conspicuous constriction on the meeting point of supraoccipital and the two frontal bones. The troglobitic status of the species is suggested by the presence of troglomorphisms on an advanced degree, especially the reduction of skin pigmentation, the total loss of eyes and the enlarged barbels. In addition, the presence of a well developed adipose fold in adults may indicate a distinctive adaptation acquired by neoteny to withstand the food scarce conditions of its hypogean habitat.

Trichomycterus dali, espécie nova, é descrita de cavernas calcárias alagadas na área cárstica da Serra da Bodoquena, estado do Mato Grosso do Sul, Brasil central. A nova espécie é diagnosticada por um caráter único no gênero, a presença de dobras adiposas conspícuas, em forma de crista, passando por toda a região dorsal do corpo. Trichomycterus dali pode ser ainda diferenciada facilmente de suas congêneres epígeas pela redução dos olhos e da pigmentação cutânea (exceto para T. gorgona), e das congêneres restantes (isto é, todas as hipógeas mais T. gorgona) pela perda total dos olhos, não visíveis externamente (exceto para T. sandovali e T. spelaeus). Outras características diagnósticas incluem barbilhões muito longos, especialmente o nasal (99,3-143,5\% do comprimento da cabeça) e o maxilar (97,0-131,3\% do comprimento da cabeça), contagem de raios da nadadeira peitoral atingindo I,9 e uma fontanela cranial única com uma constrição conspícua no ponto de encontro do supraoccipital e dos dois ossos frontais. O status troglóbio da espécie é sugerido pela presença de troglomorfismos em avançado grau, especialmente a redução da pigmentação cutânea, a perda total dos olhos e os barbilhões alongados. Além disso, a presença de uma dobra adiposa bem desenvolvida nos adultos pode indicar uma adaptação distintiva, adquirida por neotenia, para enfrentar as condições alimentares escassas do seu habitat hipógeo.

Key words. New cave fish, rio Paraguai basin, Subterranean ichthyofauna, Taxonomy, Troglobite.

\section{Introduction}

Brazil has one of the most remarkable subterranean ichthyofaunas in the world, comparable to few other countries or geographically comparable karst areas, such as Mexico, China and southeastern Asia (Bichuette \& Trajano, 2008; Trajano et al., 2009; Trajano \& Bichuette, 2010). Brazilian cave fishes are of worldwide relevance not only in terms of species richness, but also in view of the high diversity of ecologic and evolutionary patterns (Trajano \& Bichuette, 2010). Up to now, 25 troglomorphic species were reported, but many of them are still waiting for description (Trajano \& Bichuette, 2010), a process that may take several years. As the discovery rate of new possible troglobitic species still high (Trajano \& Bichuette, 2010), it will take time until the number of nominal species corresponds to a figure approaching the actual

${ }^{1}$ Universidade Federal de São Carlos, Departamento de Ecologia e Biologia Evolutiva, Via Washington Luis, km 235, Caixa Postal 676, 13565-905 São Carlos, SP, Brazil.

${ }^{2}$ Prefeitura Municipal de Bonito-MS, Secretaria Municipal de Meio Ambiente, 79290-000 Bonito, MS, Brazil.

${ }^{3}$ Universidade de São Paulo, Departamento de Zoologia, Instituto de Biociências, Caixa Postal 11461, 05422-970 São Paulo, SP, Brazil. 
subterranean fish diversity of Brazil. Despite this, the number of described species increased significantly in recent years (Fernández \& Bichuette, 2002; Bichuette \& Trajano, 2004, 2005, 2008; Bichuette et al. 2008; Moreira et al., 2010, Bockmann \& Castro, 2010), and the rate of new descriptions will surely maintain high as the already discovered species are being described.

All but two species of Brazilian troglomorphic fishes are siluriforms which belong to four families: Callichthyidae, Loricariidae, Heptapteridae and Trichomycteridae, the two latter being the most species-rich (Trajano \& Bichuette, 2010). The family Trichomycteridae is the third largest family of neotropical siluriforms, with more than 240 species of widely distributed freshwater fishes, all endemic of Central and South Americas (Nelson, 2006; Castellanos-Morales, 2008; Eschmeyer \& Fong, 2010; Datovo \& Bockmann, 2010). Its monophyly is well-corroborated and the most conspicuous synapomorphies are based on its highly specialized opercularinteropercular apparatus (de Pinna, 1998; Datovo \& Bockmann, 2010). Trichomycterids are among the most successful fishes colonizing subterranean habitats (Castellanos-Morales, 2008), and up to now there are 13 nominal species in the genera Silvinichthys, Glaphyropoma, Ituglanis and Trichomycterus (Proudlove, 2010). The latter includes the majority of described troglomorphic species: $T$. chaberti Durand, from Bolivia, $T$. spelaeus DoNascimiento, Villarreal e Provenzano, from Venezuela, T. sandovali Ardila-Rodriguez, T. santanderensis Castellanos-Morales and T. uisae Castellanos-Morales, from Colombia, and T. itacarambiensis Trajano e de Pinna, from eastern Brazil.

Trichomycterus is the most diverse trichomycterid genus, with more than 130 species already described and many others waiting for description (Alencar \& Costa, 2004; Wosiacki, 2005; Wosiacki \& de Pinna, 2008a; Fernández \& Vari, 2009). Many authors, however, point out to its non-monophyletic character (de Pinna, 1998; Wosiacki, 2002; Datovo \& Bockmann, 2010). The species-level identification is complicated by many factors, such as the scarce information available for most species (da Silva et al., 2010), and in general only those species presenting very distinctive features have been described (de Pinna, 1998; Lima \& Costa, 2004; Wosiacki $\&$ de Pinna, 2008a).

Trichomycterus catfishes occur in a great variety of habitats in South America, from Amazonian lowlands to Andean cordilleras (Fernández \& Miranda, 2007), and are frequently endemic to a single river basin (Alencar \& Costa, 2004; Lima \& Costa, 2004). These fish show a great potential to colonize extreme habitats, including subterranean habitats (Fernández \& Miranda, 2007). We describe herein a new subterranean species of the genus, which exhibits an advanced degree of troglomorphism. The species was first sampled in 1998 by Edmundo P. da Costa Jr., in limestone flooded caves in Serra da Bodoquena karst area, Paraguai river basin, Central Brazil, and since then it has been cited in literature as Trichomycterus sp. 2 (Trajano, 1997, 2003) and, later on, as Trichomycterus sp. 1 (Trajano \& Bichuette, 2004;
Mattox et al., 2008; Trajano et al., 2009; Proudlove 2010; Trajano \& Bichuette 2010).

\section{Study area}

Serra da Bodoquena is located in the State of Mato Grosso do Sul, southwestern Brazil, within the limits of the rio Paraguay basin (Fig. 1) and consists of Neoproterozoic carbonate rocks of the Corumbá Group (Almeida, 1965; Boggiani et al., 1993). This highland feature is elongated in format, oriented in a north-south direction, with a length of $200 \mathrm{~km}$ and a width varying between 10 and $70 \mathrm{~km}$.

It is possible to identify two main geomorphological compartments in the Serra da Bodoquena area (Alvarenga et al., 1982): a high calcareous massif, the Bodoquena Plateau, or the Serra da Bodoquena (sensu Almeida, 1965); and the rio Miranda lowlands, a region of lower topographic elevation, lying to the east. The Bodoquena Plateau consists of a plateau that slopes to the east, with a 200 -meter escarpment at its western border, facing towards the Pantanal region. In this rocky massif, calcareous rocks outcrop at the surface and, in those portions covered with soil, a dense forest has developed, still preserved due to difficulty of access, which has justified the creation of the "Parque Nacional da Serra da Bodoquena". The rio Miranda lowlands (Alvarenga et al., 1982), which includes the "Zona Serrana Oriental" (Eastern Highland Zone - Almeida, 1965), constitutes a vast lowland area (elevation of 100-350 m), bordered to the east by the Maracaju-Campo Grande Plateau.

In both Bodoquena Plateau and rio Miranda lowlands, the landscape is influenced by the presence of Corumbá Group carbonate rocks, which give rise to karstic surface relief with many caves, dolines and other typical features. The climate is classified as Aw (Justo, 2000), tropical with wet summer and dry winter. Monthly average temperatures are above $18^{\circ} \mathrm{C}$, with the hottest months between October and April. Annual precipitation ranges between 1000 and 2000 $\mathrm{mm}$. Various types of vegetation occur in the region, depending on topography and soil type, such as tropical forests, Cerrado (Brazilian savannah), grasslands, and the complex of the Pantanal (Galati et al., 2003). Generally, the vegetation can be characterized as a remnant of Atlantic forest in transition to Cerrado.

\section{Material and Methods}

The study specimens were hand-netted in the permanently dark zones of three flooded caves, anesthetized in benzocaine solution until death, preserved in formalin and then transferred to alcohol $70 \%$. All measurements were straight-line, taken under stereomicroscope with a dial caliper, $0.1 \mathrm{~mm}$ precision, on the left side of specimens. Measurements follow Tchernavin (1944) and de Pinna (1992). Vertebrae counts include only free vertebrae (those related to weberian complex not included) and the compound pre-ural centrum (PU1 + U1) was considered a single element. Ray counts and symbology 

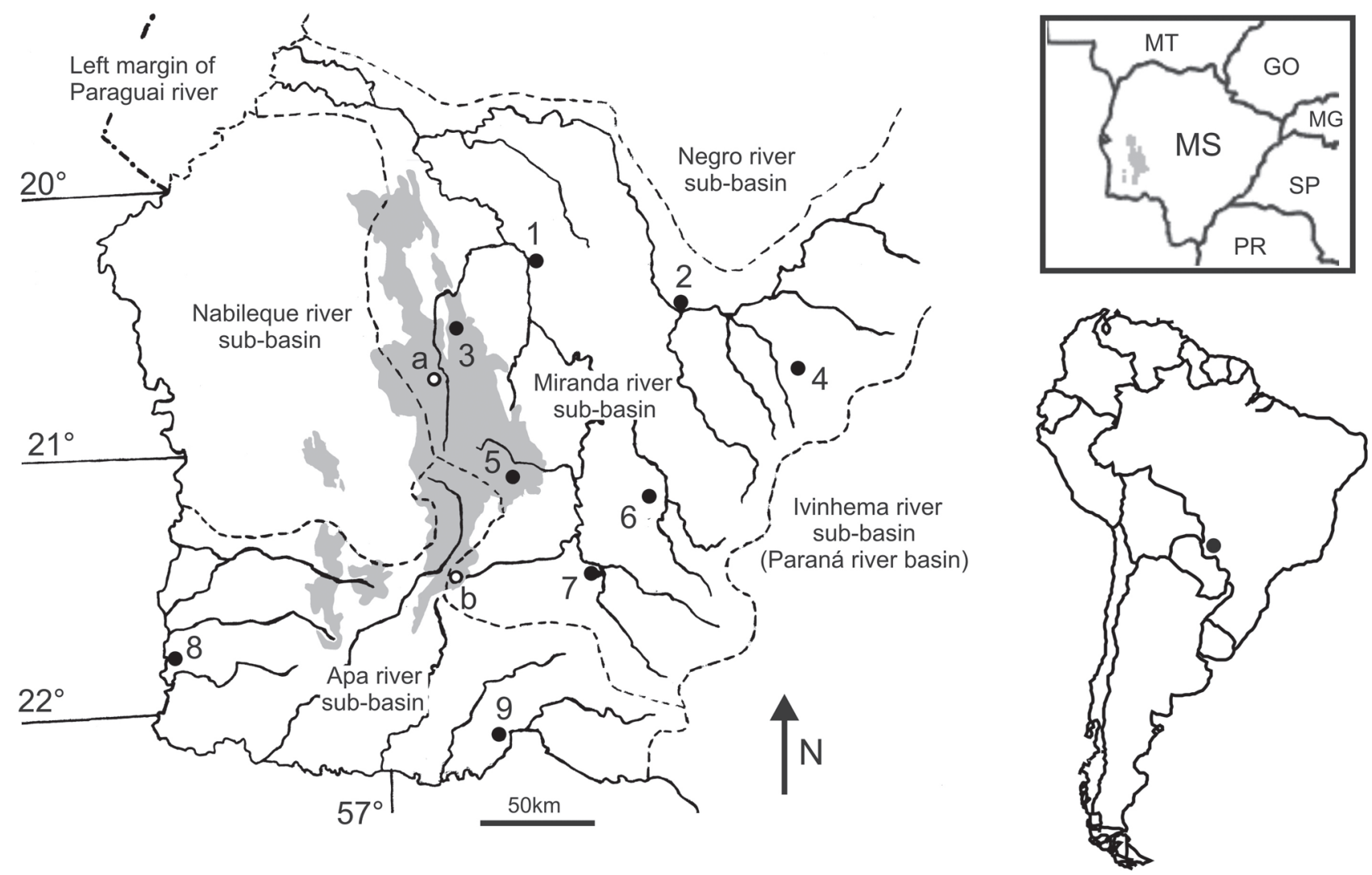

Fig. 1. Southwestern Mato Grosso do Sul state showing the principal river microbasins and area of the Bodoquena plateau (gray area). a: Morro do Jericó cave. b: Buraco das Abelhas and Saracura caves. 1: Miranda. 2: Aquidauana. 3: Bodoquena. 4: Dois Irmãos do Buriti. 5: Bonito. 6: Nioaque. 7: Jardim. 8: Porto Murtinho. 9: Bela Vista. Traced lines, limits of the river basins; continuous lines, major rivers.

follow Bockmann et al. (2004): anterior unbranched and unsegmented rays were represented by lower case Roman numerals, unbranched and segmented rays by upper case Roman numerals, and branched and segmented rays by Arabic numerals. Two type specimens were cleared and doublestained for bone and cartilage by the method of Taylor \& Van Dyke (1985). Osteological terminology follows de Pinna (1989) and Datovo \& Bockmann (2010). Abbreviations: MZUSP, Museu de Zoologia da Universidade de São Paulo; SL, standard length; HL, head length; C\&S, cleared and stained.

\section{Trichomycterus dali, new species}

(Fig. 2)

Holotype. MZUSP 106630, 78.9 mm SL, Brazil, southwestern State of Mato Grosso do Sul, Bonito, Saracura Cave (21 ${ }^{\circ}$ ' 14.6”S 5643'22.7'W, elevation $792 \mathrm{~m}$ ), rio Paraguai basin, Serra da Bodoquena karst area, 15 Jan 2006, E. P. D. Costa-Jr.

Paratypes. All from Brazil, southwestern State of Mato Grosso do Sul, rio Paraguai Basin, Serra da Bodoquena karst area. MZUSP 106631, 1, 62.4 mm SL (c\&s), Jardim, Buraco das Abelhas Cave (2129'18.24"S 5643'28.6”W, elevation 490 m), 18 Apr 1998, E. P. D. Costa-Jr. MZUSP 106632, 1, 49.0 mm SL, Jardim, Buraco das Abelhas Cave, 18 Apr 1998, E. P. D. Costa-Jr. MZUSP 81056, 1, 100.8 mm SL, Jardim, Buraco das Abelhas Cave, 19 Apr 1998, E. P. D. Costa-Jr. MZUSP 106633, 1, 47.4 mm SL, Bodoquena, Morro do Jericó Cave (2046’21.51"S 56²4'58.73"W, elevation $193 \mathrm{~m}$ ), 1 Jul 2008, E. Trajano, A. L. F. Guil \& L. M. Cordeiro. MZUSP 106634, 1, 21.6 mm SL, Bodoquena, Morro do Jericó Cave, 1 Jul 2008, E. Trajano, A. L. F. Guil \& L. M. Cordeiro. MZUSP 106635 , 1, 48.2 mm SL, Bonito, Saracura Cave, 9 Jul 2006, E. P. D. CostaJr. MZUSP 109770, 1, 72.5 mm SL (c\&s), Bonito, Buraco das Abelhas Cave.

Diagnosis. Trichomycterus dali is readily distinguished from epigean and hypogean congeners by the presence of two conspicuous, ridge-like adipose folds lining dorsally throughout the body, one anterior (pre-dorsal) and one posterior (post-dorsal) to the dorsal fin, both distinctive autapomorphies in the genus. Other characters that easily distinguish the new species, although not exclusive, are: highly reduced skin pigmentation (except for T. gorgona and caverestricted congeners, $T$. chaberti, T. itacarambiensis, $T$. spelaeus, T. sandovali, T. santanderensis and T. uisae); total loss of eyes, not visible externally (except for $T$. sandovali and T. spelaeus); barbels long, especially the nasal (99.3$143.5 \% \mathrm{HL}$ ) and the maxillary (97.0-131.3\% HL) (except for $T$. 


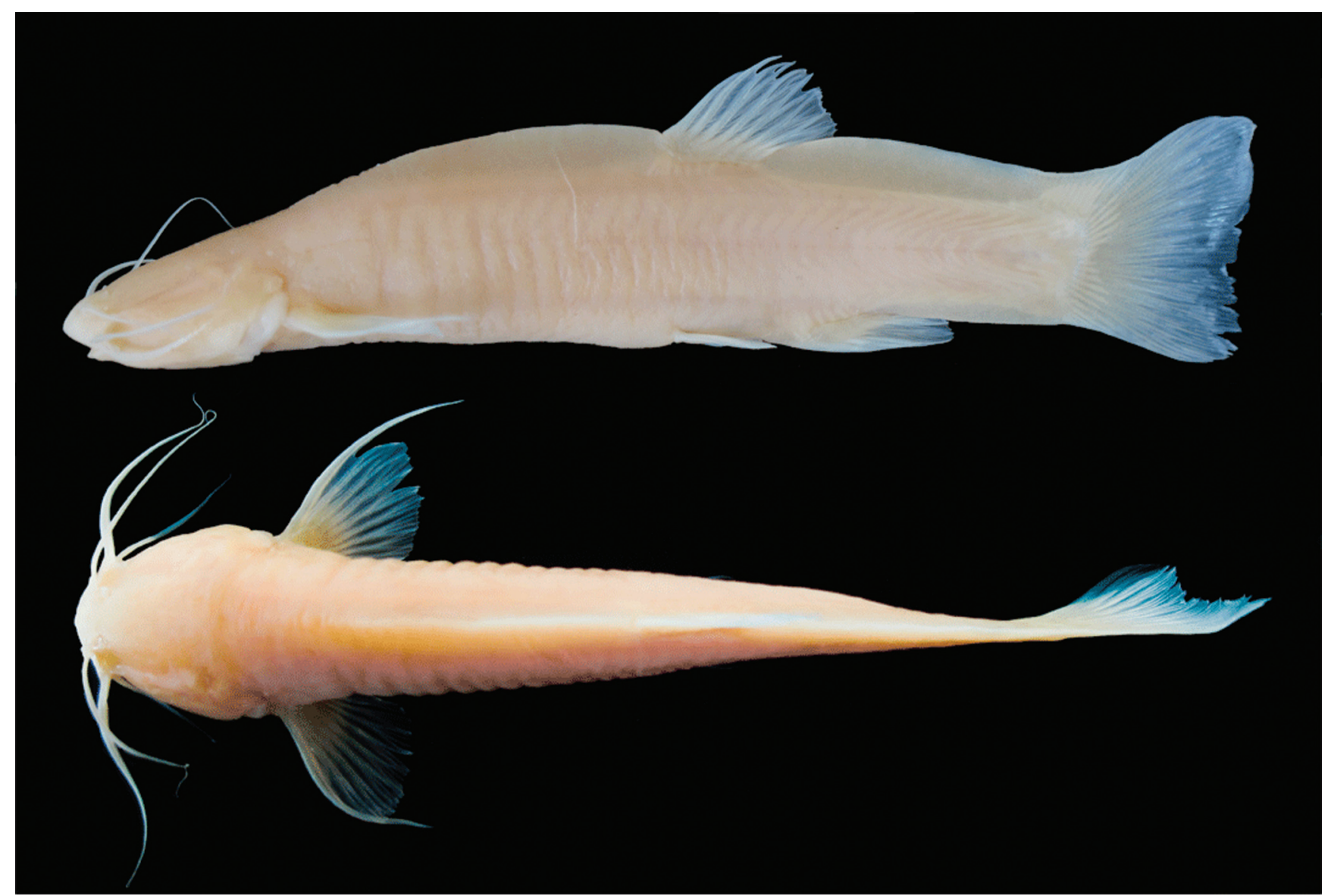

Fig. 2. Trichomycterus dali, holotype, MZUSP 106630, $78.9 \mathrm{~mm}$ SL. Brazil, Mato Grosso do Sul State, Serra da Bodoquena karst area, rio Paraguai basin, Bonito, Saracura cave. Left lateral view (above) and dorsal view (below).

longibarbatus and T. spelaeus); scapulocoracoid with a conspicuous anterior process projected forward (except for T. sandovali, T. spelaeus and T. uisae), with a narrow base, a wide apex and a rounded distal margin; and pectoral-fin ray count reaching I,9 (except for T. hualco). Characters possibly exclusive, but about which many taxa lack information, are listed as complementary diagnoses: cranial fontanel unique, extending from the posterior half of supraoccipital to the posterior region of the frontal bones, with a conspicuous constriction on the meeting point of supraoccipital and the two frontal bones; supraorbital long and cylindrical, without projections, with a needle appearance; 27-29 interopercular and 16-19 opercular odontodes.

Description. Morphometric and meristic data of holotype and paratypes given in Table 1. Body elongate, semi-cylindrical, becoming compressed towards caudal fin. Dorsal profile of body slightly convex, slight and straight slope from tip of snout to anterior portion of trunk; ventral profile of body straight in lateral view. Profile of body triangular in transversal section. Dorsal portion of caudal peduncle concave at beginning of caudal fin; ventral portion of caudal peduncle straight. Dorsal lobe of caudal fin projected upward. Adipose folds well developed in adult and young specimens, ridge- like, anterior (pre-dorsal) and posterior (post-dorsal) to dorsal fin, lining dorsally throughout body, not supported by procurrent rays. Origin of pre-dorsal adipose fold posterior to pectoral-fin base, reaching dorsal-fin base; origin of postdorsal adipose fold at end of dorsal-fin base, reaching caudal fin, with higher width closer to dorsal fin than to caudal-fin (Fig. 2). Urogenital and anal openings on vertical through posterior end of dorsal-fin base, between distal margin of pelvic fins.

Head relatively wide and depressed, trapezoidal in dorsal view. Eyes not visible externally (Fig. 3). Anterior nostril transversally ovoid and slightly smaller than posterior one, surrounded laterally by nasal barbels. Posterior nostril rounded, surrounded anteriorly by large, laterally-folded flap of integument. Mouth slightly subterminal, convex in dorsal view, rictus laterally directed. Lips, mentum and barbels covered by many papillae (Fig. 4). Barbels long, especially nasal and maxillary. Nasal barbel origin on posterolateral portion of integumentary flap around anterior nostril. When adpressed to body, maxillary barbel extending to middle of pectoral fin; nasal barbel extending to origin of pectoral fin, and submaxilary barbel extending to opercle. Opercular patch of odontodes small and circular. Interopercular odontodes forming slightly convex patch throughout ventral margin of 
Table 1. Morphometric and meristic data of holotype and the seven paratypes of Trichomycterus dali. SD, standard deviation. Ray counts of type C\&S specimens. *On the right pectoral fin, count ray was, as in the paratype, I,9.

\begin{tabular}{|c|c|c|c|c|}
\hline & Holotype & Range $(n=8)$ & Mean & SD \\
\hline Standard length & 78.9 & $21.63-100.9$ & 58.3 & 25.4 \\
\hline & \multicolumn{4}{|c|}{ Percents of Standard length } \\
\hline Total length & 114.9 & $114.6-120.6$ & 116.7 & 2.1 \\
\hline Predorsal length & 59.8 & $57.6-64.6$ & 61.1 & 2.8 \\
\hline Preanal length & 71.6 & $71.3-75.1$ & 72.3 & 1.2 \\
\hline Prepelvic length & 59.5 & $55.8-62.2$ & 58.9 & 2.0 \\
\hline Caudal peduncle length & 22.1 & $20.6-23.1$ & 21.7 & 0.8 \\
\hline Caudal peduncle depth & 16.8 & $14.2-19.3$ & 17.2 & 1.5 \\
\hline Dorsal-fin base length & 11.1 & $10.3-12.7$ & 11.1 & 0.8 \\
\hline Anal-fin base length & 8.0 & $7.9-10.2$ & 8.5 & 0.8 \\
\hline Pectoral-fin base length & 5.7 & $5.0-6.7$ & 5.9 & 0.6 \\
\hline Pelvic-fin base length & 2.7 & $2.5-3.3$ & 2.9 & 0.2 \\
\hline Dorsal-fin length & 17.1 & $15.6-19.5$ & 17.1 & 1.6 \\
\hline Anal-fin length & 16.1 & $13.8-18.9$ & 16.1 & 1.6 \\
\hline Pectoral-fin length & 20.5 & $18.4-23.8$ & 20.8 & 2.0 \\
\hline Pelvic-fin length & 10.2 & $9.3-12.5$ & 10.7 & 1.0 \\
\hline Head length & 21.1 & $19.9-22.1$ & 20.9 & 0.8 \\
\hline Body depth & 13.0 & $11.6-16.6$ & 13.6 & 1.7 \\
\hline \multirow[t]{2}{*}{ Body width } & 19.3 & $17.9-19.9$ & 19.0 & 0.7 \\
\hline & \multicolumn{4}{|c|}{ Percents of Head length } \\
\hline Head depth & 91.1 & $69.6-95.5$ & 88.2 & 9.1 \\
\hline Head width & 61.3 & $44.2-74.9$ & 63.0 & 10.1 \\
\hline Snout length & 14.0 & $13.1-26.9$ & 18.6 & 5.6 \\
\hline Maxillary barbel length & 121.8 & $97.0-131.6$ & 112.4 & 12.7 \\
\hline Rictal barbel length & 69.8 & $35.6-71.3$ & 61.9 & 12.1 \\
\hline Nasal barbel length & 122.3 & $99.3-143.5$ & 121.5 & 16.8 \\
\hline \multirow[t]{2}{*}{ Mouth width } & 60.3 & $50.5-60.3$ & 55.3 & 3.4 \\
\hline & \multicolumn{4}{|c|}{ Paratypes C\&S } \\
\hline \multirow[t]{2}{*}{ Standard length } & \multirow{2}{*}{\multicolumn{4}{|c|}{ Ray counts }} \\
\hline & & & & \\
\hline Total dorsal fin & & ii, II, 7 & \multicolumn{2}{|c|}{ ii, I, 7} \\
\hline Total pectoral fin & & I, 9 & \multicolumn{2}{|c|}{$\mathrm{I}, 8 *$} \\
\hline Total pelvic fin & & $\mathrm{I}, 4$ & \multicolumn{2}{|c|}{$\mathrm{I}, 4$} \\
\hline Total anal fin & & ii, II, 5 & \multicolumn{2}{|c|}{ i, I, 6} \\
\hline Total caudal fin & vi, I, & , 5/viii, II, 6 & \multicolumn{2}{|c|}{ vi, 6/iv, II, 6} \\
\hline
\end{tabular}

interopercle. Opercle with two processes, upper sharp and pointed backwards, lower acute, and 27-29 opercular odontodes. Interopercle with 16-19 odontodes.

General morphology of cranium: Cranial fontanel unique, extending from posterior half of supraoccipital to posterior region of frontal bones; conspicuous constriction on meeting point of supraoccipital and two frontal bones (Fig. 5). Anterior process of sphenotic and posterolateral process of frontal as conspicuous, hollow horn-like structure, inside of which emerge infraorbital sensory branches. Supraorbital long and cylindrical, without projections, and needle appearance. Palatine with convex anterior margin covered with cartilage, waist-like medial region and long, narrow posterior process, that becomes sharp on distal region and covers almost totally metapterygoid. Vomer arrow-shaped with long posterior process. Distal profile of mesethmoid straight on dorsal view, main body axis large, cornua reaching $3 / 4$ of premaxillary length. Three to five irregular premaxillary rows of conic teeth curved backwards. Rounded proximal margin of maxilla not reaching premaxilla, covering cartilaginous margin of palatine. Lower

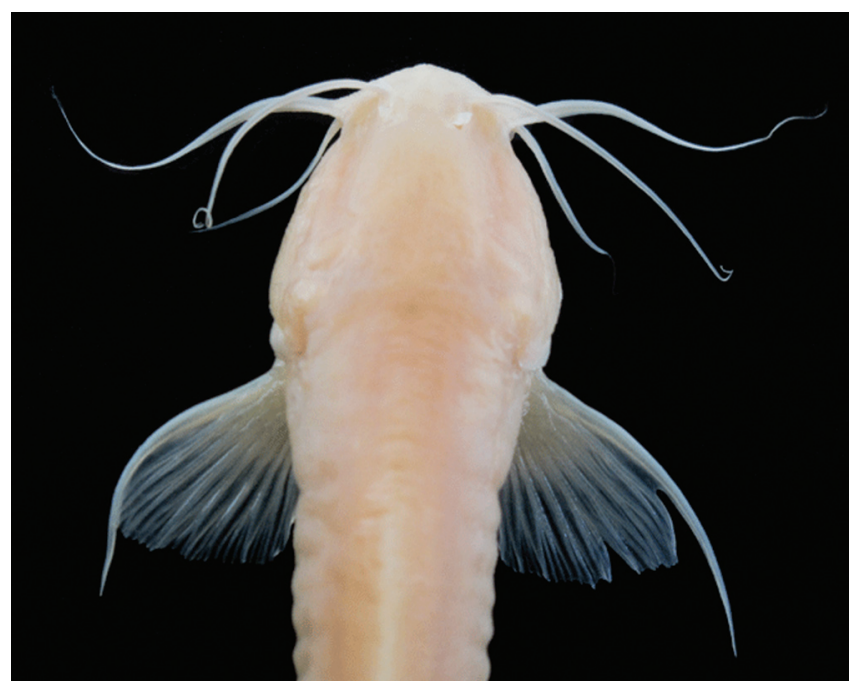

Fig. 3. Trichomycterus dali, holotype, MZUSP 106630, 78.9 $\mathrm{mm}$ SL. Brazil, Mato Grosso do Sul State, Serra da Bodoquena karst area, rio Paraguai basin, Bonito, Saracura cave. Dorsal view of head.

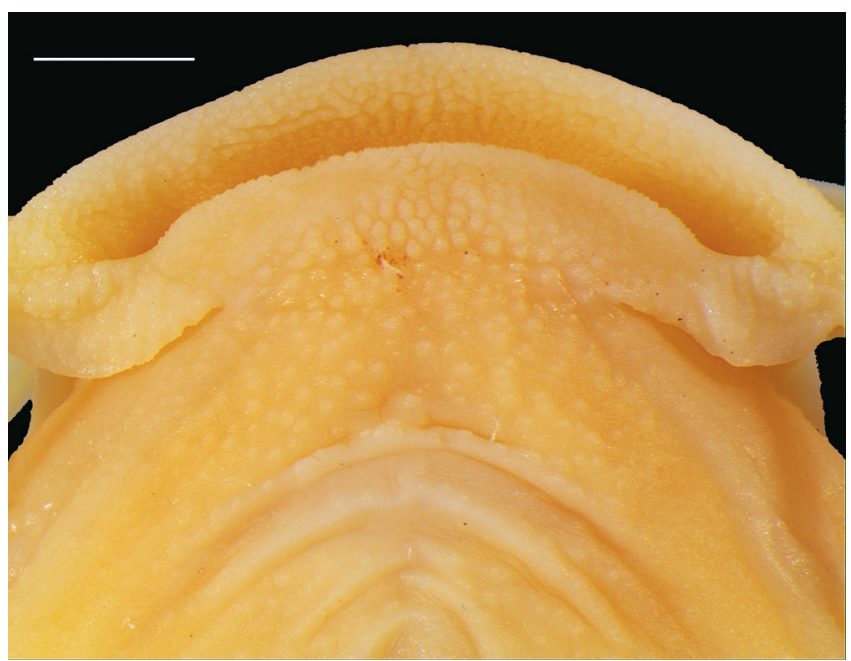

Fig. 4. Lips and mentum of Trichomycterus dali, MZUSP 106642, $49.0 \mathrm{~mm} \mathrm{SL}$, paratype, showing the abundance of papillae. Dorsal view. Scale bar $=2 \mathrm{~mm}$. Courtesy of Luciana B. R. Fernandes and Angélica M. P. M. Dias.

jaw with three rows of conical teeth, curved backwards. Hyomandibular with conspicuous semicircular depression, joined tightly to metapterygoid and quadrate. Metapterygoid and quadrate united together by anterior block of cartilage (Fig. 6).

Branchial skeleton and associated structures: Branchiostegal-rays eight, rays 5, 6 and 7 with enlarged distal tip, ray 8 covered by interopercle and reaching ventral margin of opercular patch of odontodes. Urohyal with long, very narrow dorsal process, broad convex posterior margin, lateral surface with distal margins chipped, urohyal-foramen slightly ovoid. Hypohyal with depression to which articulates anterior 


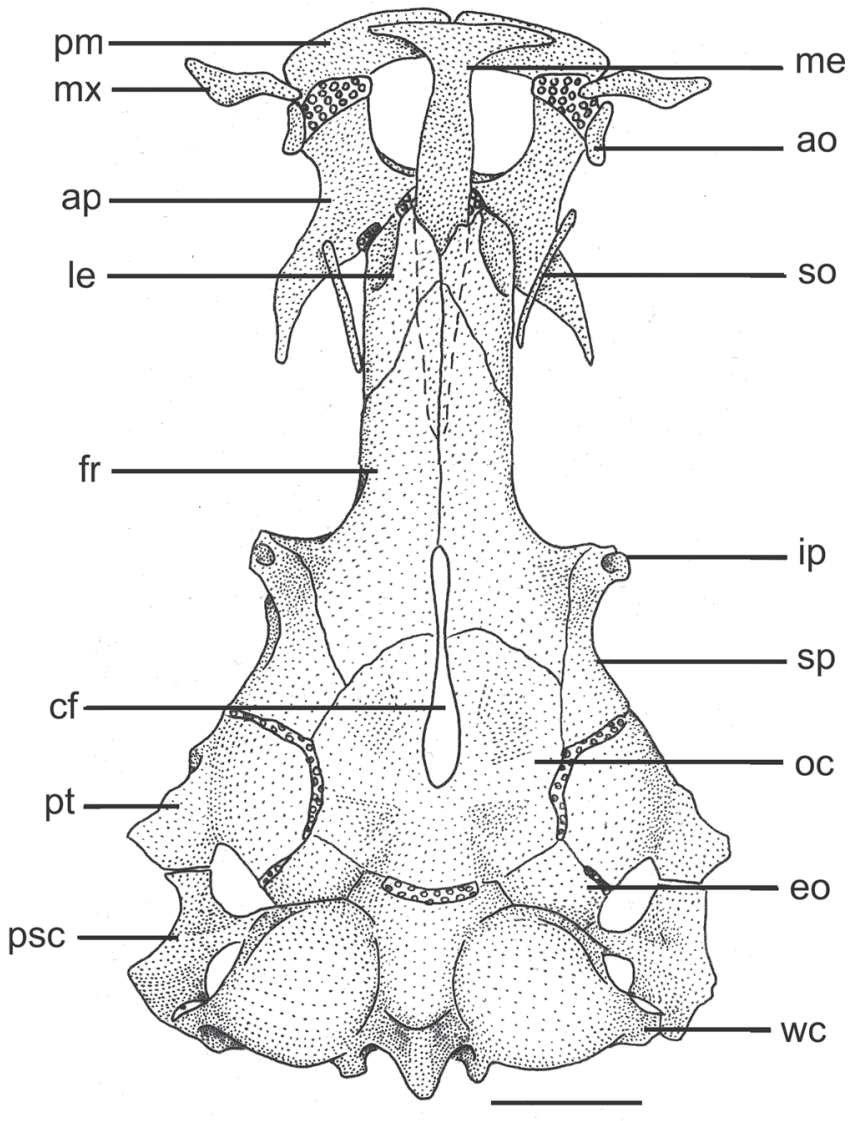

Fig. 5. Neurocranium of Trichomycterus dali, MZUSP 106631, $62.4 \mathrm{~mm}$ SL, paratype. Dorsal view. Abbreviations: ap, autopalatine; ao, antorbital; cf, cranial fontanel; eo, epioccipital; fr, frontal; ip, infraorbital process; le, lateral ethmoid; me, mesethmoid; mx, maxilla; oc, parieto-supraoccipital; pm, premaxilla; psc, posttemporosupracleithrum; pt, pterotic; so, supraorbital tendon bone; sp, sphenotic-prooticpterosphenoid complex bone; wc, weberian complex and capsule. Scale bar $=2 \mathrm{~mm}$.

process of urohyal. Posterior ceratohyal rounded triangular (Fig. 7). Basibranchials 3, hypobranchials 3, ceratobranchials 5 , epibranchials 5, pharyngobranchials 2 (Fig. 8). Basibranchial 1 absent. Basibranchial 2 and 3 connected to each other by their cartilaginous tips, forming long rod. Basibranchial 3 long and narrow, rectangular on posterior half, almost triangular on anterior half, similar to chalice. Posterior tip of basibranchial 3 covered by cartilaginous posterior portion of hypobranchials 3 . Basibranchial 4 completely cartilaginous, approximately hexagonal shaped. Anterior margins of basibranchial 4 bordered by cartilaginous posterior portion of hypobranchials 3 , lateral and posterior margins bordered by cartilaginous anterior tips of ceratobranchial 4 and ceratobranchial 5, respectively. Hypobranchial 1 with external portion wider than internal portion, with cartilaginous tips, external cartilaginous tip two to three times wider than internal. Hypobranchial 2 boomerang shaped, posterior half

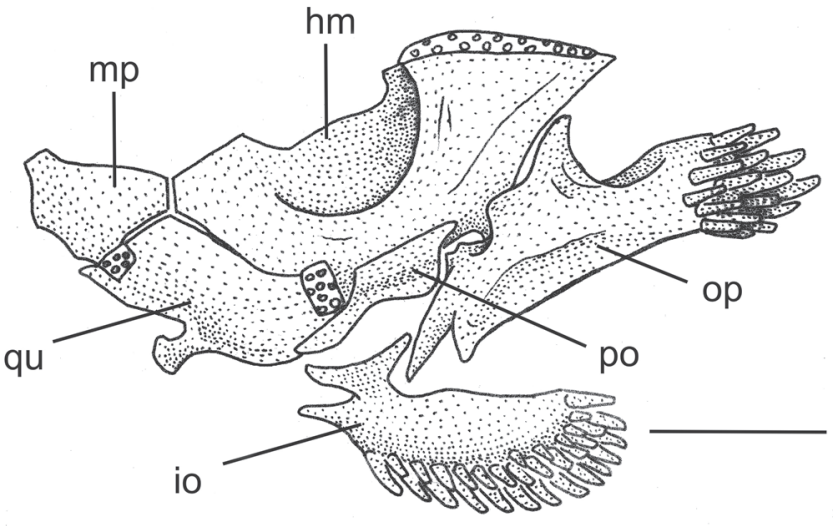

Fig. 6. Left suspensorium and opercular series of Trichomycterus dali, MZUSP 106631, 62.4 mm SL, paratype. Lateral view. Abbreviations: hm, hyomandibular; io, interopercle; $\mathrm{mp}$, metapterygoid; op, opercle; po, preopercle; qu, quadrate. Scale bar $=2 \mathrm{~mm}$.

cartilaginous, anterior half ossified, forming long anterior process that almost reaches external posterior margin of hipobranchial 1. Hypobranchial 3 almost completely cartilaginous, only anterior tip ossified in triangular shape, and closely joined to anterior cartilaginous tip of ceratobranchial 3. Hypobranchial 4 absent. Ceratobranchials slightly curved, with cartilaginous tips. Ceratobranchial 1 with internal tip wider than external tip. Ceratobranchial 2 with shallow concavity on its posterior margin, without defined posterior process. Ceratobranchial 3 with pronounced concavity on its posterior margin, limited posteriorly by very small process. Ceratobranchial 5 slightly enlarged, bearing patch of small, narrow conical teeth pointed dorsally on its anterior half, and connected to epibranchial 5 only by upper half of posterior margin. Ceratobranchials 3,4 and 5 bearing one row of conical, very sharp teeth, on posterior margin of ceratobranchial 3 , on both margins of ceratobranchial 4 , and on anterior margin of ceratobranchial 5. Epibranchials 1, 2 and 3 narrow, rod-like, with cartilaginous tips. Epibranchial 1 with long, narrow and sharp anterior process, pointed outwards in acute angle. Epibranchial 2 with small, acute process, not uncinate. Epibranchial 3 with conspicuous, posteriorly directed, large uncinate process. Epibranchial 4 large, curved, with wide dorsal margin slightly convex joined to posterior half of tooth plate, covered with cartilage, and with ventral margin very narrow, ovoid and cartilaginous, joined to posterior cartilaginous tip of ceratobranchial 4 . Epibranchial 5 very small, curved and completely cartilaginous. Pharyngobranchials 1 and 2 absent. Pharyngobranchial 3 elongate, rod-like, slightly depressed, cartilaginous tips. Pharyngobranchial 4 ossified, curved, ventral margin cartilaginous, joined tightly to anterodorsal half of tooth plate. Tooth plate well developed, curved, one row of long, conic, internally curved teeth, anteriormost of which smaller, posteriormost gradually larger. 


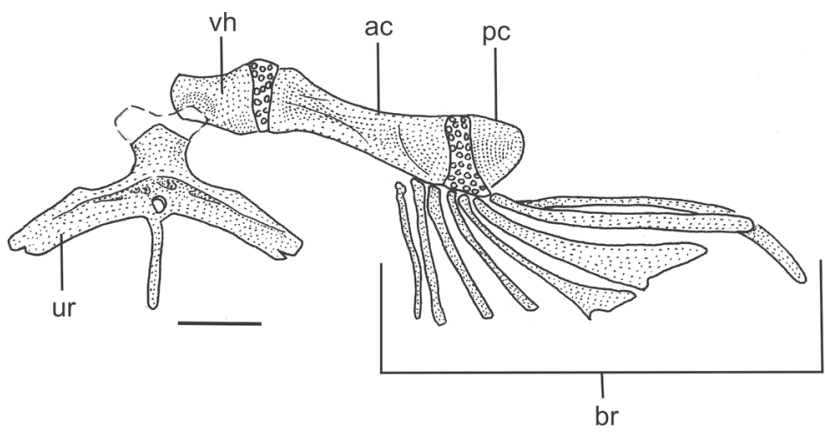

Fig. 7. Left hyoid arch of Trichomycterus dali, MZUSP 106631, $62.3 \mathrm{~mm}$ SL, paratype. Ventral view. Abbreviations: ac, anterior ceratohyal; br, branchiostegal rays; pc, posterior ceratohyal; ur, urohyal; vh, ventral hypohyal. Scale bar $=2 \mathrm{~mm}$.

Postcranial skeleton. Total vertebrae 34-35, 10-11 pairs of ribs. First ribs thicker, posteriormost gradually thinner. Pectoral girdle with wide cleithrum, becoming narrower at anterior half, joined together by very narrow anterolateral margin. Posterior process of pectoral girdle reaching lower surface of posttemporosupracleithrum. Scapulocoracoid with conspicuous anterior process projected forward, with narrow base, wide apex and rounded distal margin. Proximal radial 1 cartilaginous, joined to first and second pectoral-fin rays. Proximal radial 2 very small, cartilaginous, joined to third pectoral-fin ray. Proximal radial 3 large and well ossified, with semicircular cartilaginous posterior margin joined to fourth to tenth pectoral-fin rays, and small, ovoid anterior cartilaginous margin, joined to scapulocoracoid (Fig. 9). Pelvic girdle with external anterior process narrower and slightly longer than internal anterior process. A short medial process may occur (Fig. 10). Epural absent. Neural spine $(n=1)$ of preural centrum reduced to almost one-fourth of uroneural length, rounded tip projected upward. Hemal spine of penultimate vertebrae with cartilaginous tip and bearing one procurrent ray. Parhypural partially fused to hypural $1+2$, forming trapezoidal lower hypural plate. Hypural 3 not fused to Hypural 4+5. Uroneural with acute distal tip, not fused to Hypural 4+5, long, reaching distal margin of upper hypural plate. Upper hypural plate triangular. Lower apophysis of preural centrum projected forward, with acute tip (Fig. 11).

Pectoral fin triangular in dorsal view, with wide base and ten rays, first ray longer, unbranched and filamentous (I,9). On one type C\&S specimen, left pectoral fin counted I,8. Dorsal fin approximately semicircular in lateral view, with nine rays, the two first unbranched; in addition, two micro rays anterior to first ray (ii,II,7). Pterygiophores with eight narrow basal radials on dorsal fin, curved on basal portion, with espatulate distal region curved backwards and cartilaginous distal tip. First basal radial has two folds backwards and narrow cartilaginous distal margin pointing backwards. Last basal radial with laminar posterior expansion on its distal fold, joined to two last dorsal-fin rays. Each basal radial, except for first, joined to small, half cartilaginous half ossified distal radial,

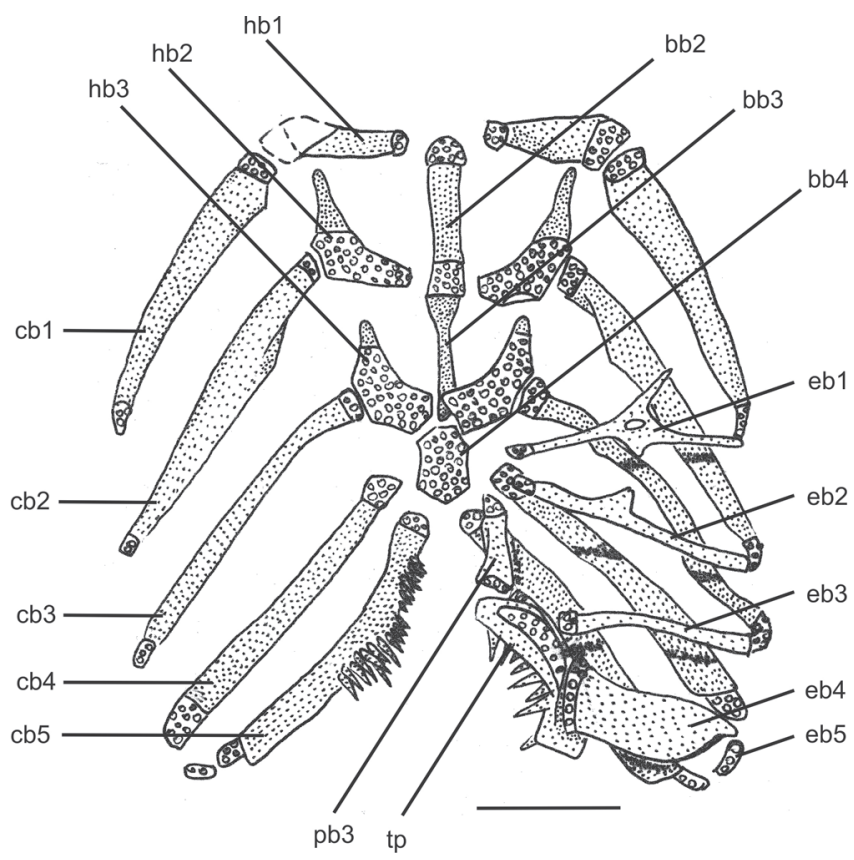

Fig. 8. Branchial skeleton of Trichomycterus dali, MZUSP 109770, $72.5 \mathrm{~mm}$ SL, paratype. Dorsal view. Abbreviations: bb2-4, basibranchials 2 to 4 ; cb1-5, ceratobranchials 1 to 5 ; eb1-5, epibranchials 1 to 5 ; hb1-3, hypobranchials 1 to 3 ; pb3, pharyngobranchial 3 ; tp, tooth plate. Scale bar $=2 \mathrm{~mm}$.

between two basal branches of each ray. Anal fin approximately rectangular in lateral view, distal margin straight, with seven rays; in addition two micro rays anterior to first ray (ii,II,5). On one type $\mathrm{C} \& \mathrm{~S}$ specimen, ray count varied, and presented as one micro ray, I,6, being the micro ray branched (Table 1). Pterygiophores with six narrow basal radials on anal fin, morphologically similar to dorsal pterygiophores: with espatulate, curved distal region, cartilaginous tips, first with two folds, last with laminar posterior expansion holding two last rays, each basal radial except first joined to small distal radial half ossified half cartilaginous between two basal branches of each ray. Pelvic fin rectangular in ventral view, separated from each other, with five rays, first ray unbranched $(I, 4)$. Origin of pelvic-fin base on vertical line through origin of dorsal-fin base. Margin of caudal fin straight, 14 principal rays (six in upper lobe, first branched or unbranched; eight in lower lobe, two first unbranched). On upper lobe, first three (uppermost) principal rays joined to hypural $4+5$, next three joined to hypural 3 . On lower lobe, first (lowermost) principal ray begins in gap between hemal spine of penultimate vertebrae and parhypural, second joined to parhypural and other joined to hypural $1+2$. Six dorsal procurrent rays; ventral procurrent rays varying from 4 to 8 (counts of c\&s paratypes, see Table 1).

Color in alcohol. Body generally pale yellowish, dorsal ridge (anterior and posterior to dorsal fin) brighter than body and 


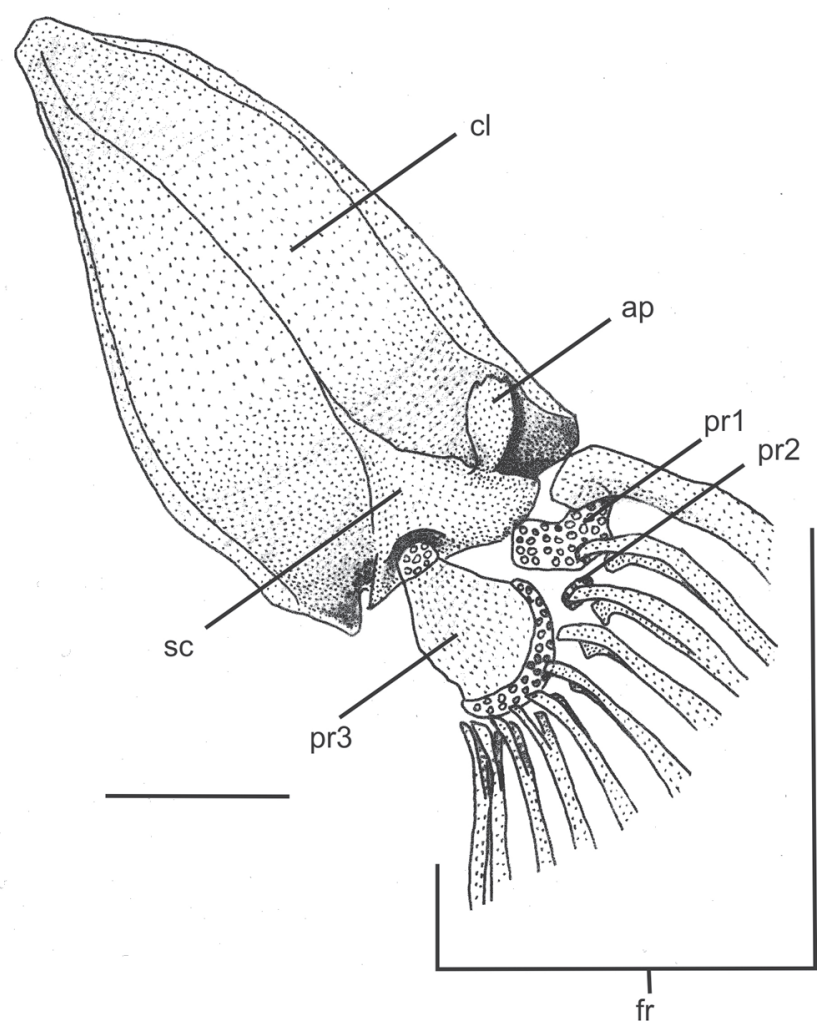

Fig. 9. Left pectoral girdle of Trichomycterus dali, MZUSP 106631, $62.4 \mathrm{~mm}$ SL, paratype. Ventral view. Abbreviations: ap, anterior process; cl, cleithrum; fr, fin rays; pr1-3, proximal radials 1 to 3 ; sc, scapulocoracoid. Scale bar $=2 \mathrm{~mm}$.

tending to translucent. Mouth and barbels light yellowish pale to white. Pectoral, dorsal, pelvic, anal and caudal fins hyaline (Fig. 2).

Color in life. Body generally white, tending to translucent, dorsal ridge darker than body, with light yellow color. Internal organs seen by transparency (Fig. 12).

Etymology. The specific name (a noun in apposition) is an allusion to the Spanish artist Salvador Dali, in reference to his famously long moustache (or whisker).

Distribution. Trichomycterus dali is known exclusively from subterranean waters in at least three caves in Serra da Bodoquena karst area: Buraco das Abelhas, Saracura and Morro do Jericó caves.

Notes on habitat, ecology and behavior. The Buraco das Abelhas Cave is an underwater cave, with more than $2000 \mathrm{~m}$ of explored conduits and maximum depths of $55 \mathrm{~m}$, located in the southern portion of Serra da Bodoquena National Park, in the rio Miranda lowlands. The only cave entrance so far known opens into a large room with a lake, whose level

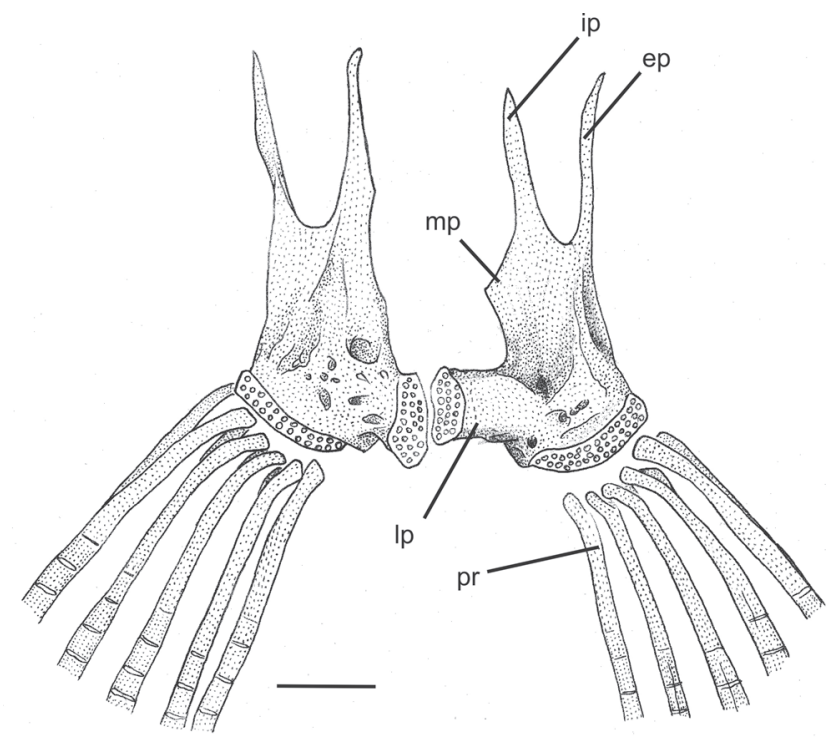

Fig. 10. Pelvic girdle skeleton of Trichomycterus dali, MZUSP 109770, 72.5 mm SL, paratype. Ventral view. Abbreviations: ip, internal anterior process; ep, external anterior process; lp, lateral process; mp, medial process; pr, pelvic fin rays. Scale bar $=2$ $\mathrm{mm}$.

increases during rain seasons, completely flooding the saloon and only allowing access through cave diving from the entrance. The cave continues as a large, $1200 \mathrm{~m}$ long flooded conduit, called tunnel A. Two hundred meters from the entrance, on the right side, the tunnel A branches into tunnel $\mathrm{B}, 700$ meters long and depth varying from 40 meters to up to 12 meters at the distal explored end of the conduit. Eight hundred meters far from the cave entrance, again on the right side of tunnel A, opens tunnel C; 200 meters inside tunnel C, on the left, tunnel D starts, going to a depth of up to 12 meters. Non-troglomorphic fish, such as the catfish Rhamdia quelen and tetra characins, Astyanax spp., were observed regularly in the entrance room, and farther in tunnel A until $200 \mathrm{~m}$ from the cave entrance, reaching a depth of $49 \mathrm{~m}$. At 100 meters from the cave entrance, $12 \mathrm{~m}$ deep, these fish become syntopic with $T$. dali.

The Saracura Cave small entrance opens into a $230 \mathrm{~m}$ long dry conduit with a travertine lake at its distal end accessing a large underwater cave, not totally explored so far. The underwater portion starts with a nearly vertical drop into a 4 $\mathrm{m}$ diameter tunnel, becoming horizontal at the depth of $60 \mathrm{~m}$. The last exploratory dive took 130 meters of guidelines and ended at a depth of $65 \mathrm{~m}$ in a huge horizontal tunnel still to be explored.

The Jericó Cave has three small entrances opening in the Salobra canyon. It is predominantly horizontal, with dry conduits about $15 \mathrm{~m}$ high and $2 \mathrm{~m}$ wide. Trichomycterus dali specimens were collected in a large pool at the distal end of the lower conduit, which is partially filled by sandy sediments. During the collections (mid-dry season), maximum depth in the pool was about $1 \mathrm{~m}$, width was $2.5 \mathrm{~m}$ and extension, $4 \mathrm{~m}$; 


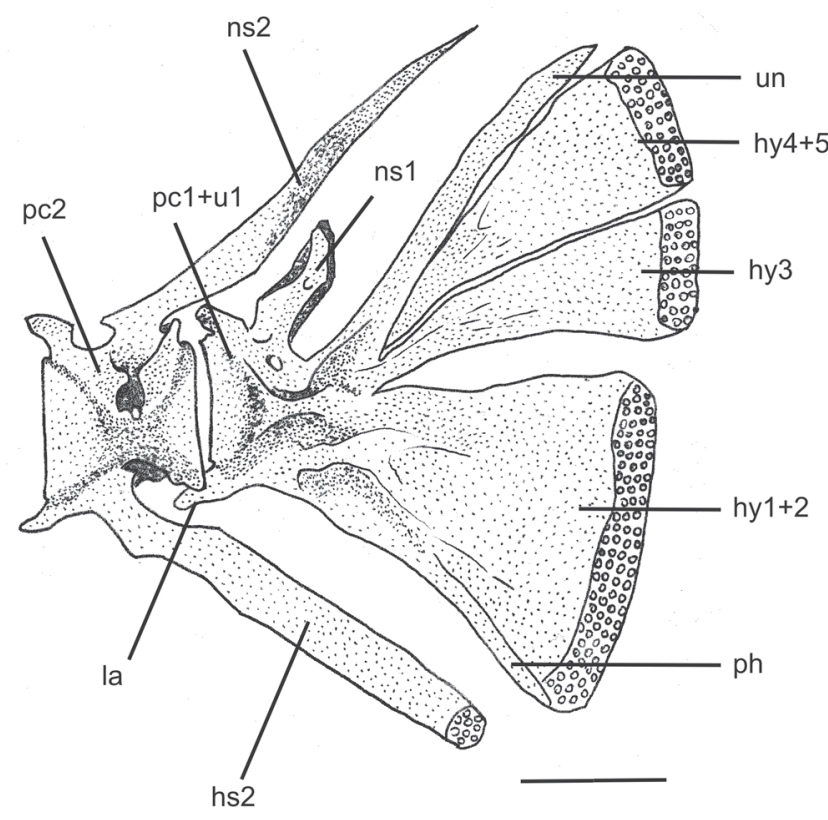

Fig. 11. Caudal skeleton of Trichomycterus dali, MZUSP 106631, $62.4 \mathrm{~mm}$ SL, paratype. Left lateral view. Abbreviations: ns1-2, neural spines of preural centrum 1 and 2; hy1+2, complex plate formed by co-ossification of hypurals 1 and 2; hy3, hypural 3; hy $4+5$, complex plate formed by co-ossification of hypurals 4 and 5; la, lower apophysis of preural centrum 1; pc1+u1, complex centrum composed of preural centrum 1 and ural centrum 1; pc2, preural centrum 2; ph, parhypural, partially fused to hy1+2; un, uroneural; hs2, hemal spine of preural centrum 2 . Scale bar $=2 \mathrm{~mm}$.

water flowed slowly transverly to the conduit (L. M. Cordeiro, pers. comm.).

Trichomycterus dali catfishes can be found in the permanently dark areas zone, calmly swimming in the water column and close to the rocky substrate (bottom and walls). In Buraco das Abelhas, individuals were observed from 12 up to 55 meters deep (maximum depth of the cave system); in Saracura cave, fish swim from near the surface up to a depth of 65 meters, where the main tunnel stops dropping down and become horizontal. The light from halogen underwater spotlights, $50 \mathrm{~W}$, used at the time the first specimens were collected, as well as from 10 to 20W HID spotlights used more recently, did not trigger any visible reaction in these fishes. Cave divers also seem not to disturb the fishes, but, as one try to catch them, they start to swim very fast towards the deeper parts of the caves, against the current, near the bottom and into small crevices. Sometimes they were observed digging the soft bottom of Buraco das Abelhas.

After being hand netted at depths of up to $65 \mathrm{~m}$, the specimens brought to the surface did not exhibit any reactions related to pressure reduction. Several specimens were kept alive in small water boxes, aired with battery powered air pumps during at least a week and, then, traveled 1,200 km until the laboratory in São Paulo. Three specimens collected in 2000 and 2001 were still alive in 2010.

\section{Discussion}

Taxonomy. To date, more than 130 valid species are assigned to the genus Trichomycterus, of which more than 60 occur in Brazil (Eschmeyer \& Fong, 2010), in addition to many others presently in the process of or awaiting for description (Alencar \& Costa, 2004; Wosiacki, 2005; Wosiacki \& de Pinna, 2008a; Fernández \& Vari, 2009), turning the genus into the most species-rich within the family (de Pinna, 1998; Wosiacki \& de Pinna, 2008b; Fernández \& Vari, 2009; Eschmeyer \& Fong, 2010). Nevertheless, as mentioned above, the evolutionary relationships and phylogenetic history of the genus are still obscure (Wosiacki \& de Pinna, 2008a), and many authors point out to its non-monophyletic character (de Pinna, 1998; Wosiacki, 2002), making the identification of new species of Trichomycterus very complicated (Wosiacki, 2005; da Silva et al., 2010). For this reason, only species with broadly distinctive features, which can be easily recognized as new taxa, have been recently described (de Pinna, 1998; Wosiacki $\&$ de Pinna, 2008b). Moreover, due to the lack of synapomorphic characters distinguishing the genus Trichomycterus, it has been included those species lacking the synapomorphies accepted for Bullockia, Eremophilus, Hatcheria, Ituglanis, Rhizosomichthys, Scleronema, and Silvinichthys, as proposed by Arratia (1990, 1998), Costa and Bockmann (1993), and Fernández and de Pinna (2005). As a result, Trichomycterus is nowadays a large assemblage of species not necessarily closely related (Wosiacki \& de Pinna, $2008 \mathrm{~b}$ ). Because none of the synapomorphies of other Trichomycterinae genera could be recognized for the new species from Serra da Bodoquena, its inclusion in Trichomycterus seems to be the most reasonable alternative for the moment.

Trichomycterus dali is a very distinctive species, especially due to four easily noticeable characters: (a) high degree of reduction on melanic skin pigmentation, character that differentiates the new species from all epigean congeners, except for $T$. gorgona; (b) eyes reduced, not visible externally, which also distinguishes the new species from all epigean congeners (including T. gorgona) and further differentiates it from all cave-restricted congeners except for T. spelaeus and T. sandovali; (c) very long barbels, especially the nasal and the maxillary ones, which may distinguish the new species from other congeners, except for T. longibarbatus (epigean) and T. spelaeus (hypogean) and represents one of the longest barbels within the genus; and (d) presence of very conspicuous adipose ridges in both young and adult individuals, lining dorsally throughout the body, which differentiates the new species form all of its congeners, both epigean and hypogean, including $T$. gorgona, T. longibarbatus, T. spelaeus and T. sandovali. The three first characters are clearly related to its subterranean habit, because reduction of eyes and 


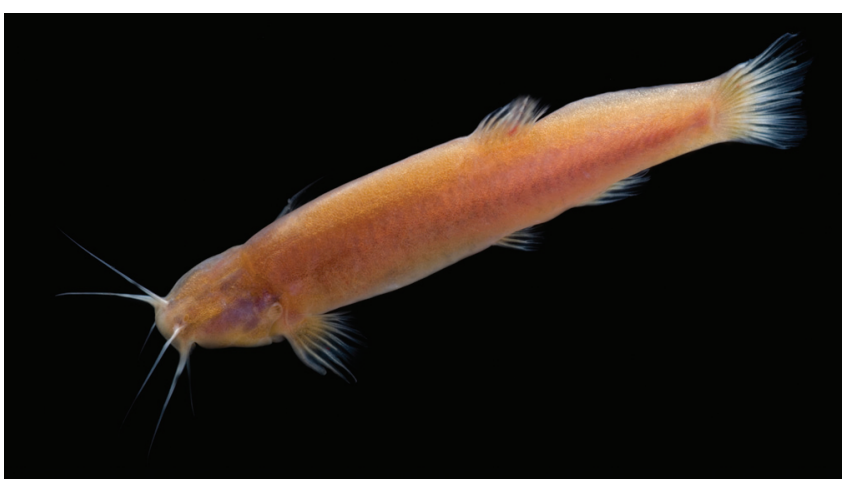

Fig. 12. Trichomycterus dali, adult, live specimen photographed in aquarium on May, 2011, unpreserved; Brazil, Mato Grosso do Sul State, Serra da Bodoquena karst area, rio Paraguai basin, Jardim, Buraco das Abelhas cave. Courtesy of Dante Fenolio.

pigmentation and enlargement of appendages bearing sensorial structures are broadly recognized as the commonest traits characterizing troglobites (Hüppop, 2000; Trajano, 2001), and these characters are commonly used in descriptions of exclusively hypogean fishes (Renno et al., 2007). The fourth, although not characteristic of troglobites and even present in epigean species of the family, may be possibly related to its subterranean habit, as we discuss below (see Adipose folds).

Among the six cave-restricted Trichomycterus previously described, only T. itacarambiensis occurs in Brazil, in the upper rio São Francisco basin, separated from the Paraguai basin, where $T$. dali occurs, by the large rio Paraná basin. Trichomycterus dali may be distinguished from $T$. itacarambiensis by the complete absence of externally visible eyes ( $v s$. large intraespecific variation in eye development in the latter), the highly reduced skin pigmentation, with color pattern pale yellowish to bright white (vs. color pattern composed of small irregular, roundish black spots), the origin of pelvic fin on the vertical line through origin of dorsal fin base ( $v s$. base of pelvic fin slightly anterior to vertical through origin of dorsal fin) and by longer barbels (see Table 2).

Among the other troglomorphic species of the genus, $T$. dali may be distinguished from: (1) T. spelaeus, by the ventral profile of body straight (vs. slightly convex in the latter), the head trapezoidal in dorsal view (vs. triangular), the anal fin approximately rectangular in lateral view with distal margin straight (vs. rounded, distal margin semicircular) and by the single cranial fontanel ( $v s$. two cranial fontanels, anterior and posterior, separated by epiphyseal bar); (2) T. chaberti, by the absence of eyes ( $v s$. presence, in variable degree among individuals), the highly reduced skin pigmentation ( $v s$. variable, moderately pigmented, yellowish with brown spots), the origin of pelvic fin on the vertical line through origin of dorsal-fin base ( $v s$. vertical line through origin of dorsal fin located at the end of pelvic fin), the origin of anal fin posterior to the end of dorsal-fin base (vs. origin of anal fin below the dorsal fin base), and the profile of caudal fin, with a conspicuous constriction on the origin of rays and a upper lobe projected upward (vs. dorsal and ventral profile straight); (3) $T$. sandovali, by the head trapezoidal in dorsal view ( $v s$. triangular), the lateral profile of head straight ( $v s$. semicurve) and the cranial fontanel unique (vs. two cranial fontanels, anterior and posterior, separated by epiphyseal bar); (4) $T$. santanderensis, by the complete absence of eyes ( $v s$. presence, variable from visible to imperceptible), the highly reduced skin pigmentation ( $v s$. variable from homogeneous light-red on adults to pale rose with small, gray, dorsal round spots on young individuals), the profile of caudal fin, with a constriction on the origin of rays, dorsal lobe projected upward (vs. dorsal and ventral profile slightly convex), the head trapezoidal in dorsal view ( $v s$. triangular), and the longer head, ranging from 19.9 to $22.1 \% \mathrm{SL}(v s .18 .2-18.9 \% \mathrm{SL}$ ); (5) T. uisae, by the absence of eyes ( $v s$. presence, reduced but well defined, ranging from 7.4 to $11.1 \% \mathrm{HL}$ ), the highly reduced skin pigmentation ( $v s$. reduced pigmentation, consisting of ground coloration light brow without spots and a narrow predorsal bluish-gray stripe), origin of the pelvic fin on the vertical line through origin of dorsal-fin base ( $v s$. origin of pelvic fin anterior to vertical through origin of dorsal fin), the profile of caudal fin, with a constriction on the origin of rays, dorsal lobe projected upward ( $v s$. dorsal and ventral profile slightly convex), and the single cranial fontanel (vs. two cranial fontanels, anterior and posterior, separated by a narrow channel) (see Table 2).

Troglobitic status. According to the classical SchinerRacovitza system, troglobites are defined as organisms restricted to subterranean habitats, incapable to form epigean source populations, in opposition to troglophyles, that may form source populations both in epigean and hypogean habitats, and trogloxenos, regularly found in subterranean habitats, but which, to be able to complete their life cycle, must leave such habitats periodically (Barr, 1968; Holsinger \& Culver, 1988; Trajano, 2005, 2010). It is logically impossible (see Trajano \& Bichuette, 2010), to demonstrate the absence of some biological feature in a given area, and the only practical solution is a statistical approach, based on a surveying effort high enough to test the sampling sufficiency (such as species accumulation curves). Unfortunately, this condition is rarely achieved. Therefore, the practice has become to use autapomorphic character states to deduce the troglobitic status, specially the so-called classical troglomophisms, with emphasis on reduction of ocular structures and melanic pigmentation, and also hyperdevelopment of sensorial structures, in relation to closely related epigean species (e.g., Culver \& Pipan, 2009).

Extensive fish collections have been made in several epigean streams of Serra da Bodoquena area, but only one Trichomycterus specimen was found (L.C. Medeiros \& R. Borghezan, pers. comm.), indicating very low densities and/ or very localized distributions of epigean populations. 
Table 2. Comparative data on external morphology of Trichomycterus subterranean species.

\begin{tabular}{|c|c|c|c|c|c|c|c|}
\hline & T. dali & T. itacarambiensis & T. spelaeus & T. chaberti & T. sandovali & T. santanderensis & T. uisae \\
\hline Eyes & Not visible & $\begin{array}{c}\text { Presence, } \\
\text { intraespecific } \\
\text { variation }\end{array}$ & Not visible & $\begin{array}{c}\text { Presence, variable } \\
\text { degree among } \\
\text { individuals } \\
\end{array}$ & Not visible & $\begin{array}{l}\text { Presence, from visible to } \\
\text { imperceptible }\end{array}$ & $\begin{array}{l}\text { Presence, reduced } \\
\text { but well defined }\end{array}$ \\
\hline $\begin{array}{l}\text { Skin } \\
\text { pigmentation }\end{array}$ & $\begin{array}{l}\text { Pale yellowish to } \\
\text { bright white }\end{array}$ & $\begin{array}{l}\text { Small, irregular } \\
\text { roundish black } \\
\text { spots }\end{array}$ & $\begin{array}{l}\text { Bright yellow to } \\
\text { light brow }\end{array}$ & $\begin{array}{l}\text { Variable, } \\
\text { moderately } \\
\text { pigmented, } \\
\text { yellowish with } \\
\text { brown spots }\end{array}$ & Bright yellow & $\begin{array}{c}\text { Variable from } \\
\text { homogeneous light-red to } \\
\text { pale rose with small gray, } \\
\text { dorsal round spots }\end{array}$ & $\begin{array}{l}\text { Reduced, light } \\
\text { brown without } \\
\text { spots, narrow } \\
\text { predorsal bluish- } \\
\text { gray stripe } \\
\end{array}$ \\
\hline $\begin{array}{l}\text { Origin of } \\
\text { pelvic fin }\end{array}$ & $\begin{array}{l}\text { On vertical through } \\
\text { origin of dorsal fin } \\
\text { base }\end{array}$ & $\begin{array}{l}\text { Slightly anterior to } \\
\text { origin of dorsal fin }\end{array}$ & $\begin{array}{l}\text { On vertical } \\
\text { through origin of } \\
\text { dorsal fin base }\end{array}$ & $\begin{array}{l}\text { Anterior to origin } \\
\text { of dorsal fin }\end{array}$ & $\begin{array}{l}\text { On vertical } \\
\text { through origin } \\
\text { of dorsal fin } \\
\text { base }\end{array}$ & $\begin{array}{l}\text { On vertical through } \\
\text { origin of dorsal fin base }\end{array}$ & $\begin{array}{c}\text { Anterior to origin of } \\
\text { dorsal fin }\end{array}$ \\
\hline $\begin{array}{l}\text { Ventral } \\
\text { profile of } \\
\text { body }\end{array}$ & Straight & $\begin{array}{l}\text { Slightly convex or } \\
\text { nearly straight }\end{array}$ & Slightly convex & Slightly concave & $\begin{array}{l}\text { Slightly } \\
\text { concave }\end{array}$ & Straight & Straight \\
\hline $\begin{array}{l}\text { Dorsal view } \\
\text { of head }\end{array}$ & Trapezoidal & Trapezoidal & Triangular & Triangular & Triangular & Triangular & Trapezoidal \\
\hline $\begin{array}{l}\text { Anal fin in } \\
\text { lateral view }\end{array}$ & $\begin{array}{l}\text { Rectangular, distal } \\
\text { margin straight }\end{array}$ & Half-ellipsoidal & $\begin{array}{l}\text { Rounded, distal } \\
\text { margin } \\
\text { semicircular }\end{array}$ & (unobtained data) & $\begin{array}{l}\text { Distal margin } \\
\text { rounded }\end{array}$ & Rounded & Rounded \\
\hline $\begin{array}{l}\text { Profile of } \\
\text { caudal fin }\end{array}$ & $\begin{array}{c}\text { With a constriction } \\
\text { on the origin of rays, } \\
\text { dorsal lobe projected } \\
\text { upward }\end{array}$ & $\begin{array}{l}\text { Dorsal and ventral } \\
\text { profile slightly } \\
\text { convex }\end{array}$ & $\begin{array}{c}\text { Dorsal and } \\
\text { ventral profile } \\
\text { slightly convex }\end{array}$ & $\begin{array}{l}\text { Dorsal and ventral } \\
\text { profile straight }\end{array}$ & $\begin{array}{c}\text { Dorsal and } \\
\text { ventral profile } \\
\text { slightly convex }\end{array}$ & $\begin{array}{l}\text { Dorsal and ventral profile } \\
\text { slightly convex }\end{array}$ & $\begin{array}{l}\text { Dorsal and ventral } \\
\text { profile slightly } \\
\text { convex }\end{array}$ \\
\hline
\end{tabular}

Although these collecting efforts are still insufficient for a conclusive statement of restriction to cave habitats, the association with advanced troglomorphic traits in $T$. dali, indicating a long process of differentiation in isolation in the subterranean habitat, strongly corroborates the hypothesis of a troglobitic status for this species.

Representatives of the family Trichomycteridae have been very successful in colonizing subterranean environments (Reis et al., 2006; Castellanos-Morales, 2007), with troglobitic and troglophilic populations (Mattox, 2008). Troglomorphic representatives of the family can be found in five genera, the Argentinian Silvinichthys (one troglobitic species), the Brazilian Copionodon (one species), Glaphyropoma (one species) and Ituglanis (six species), and the widespread Trichomycterus (nine species, including two to be described) (Proudlove, 2010). In all trichomycterids referred to as troglobites, reduction of eyes and pigmentation at some extent, as well as long barbels, have been reported (DoNascimiento et al., 2001; Romero \& Paulson, 2001; Bichuette \& Trajano, 2008; Castellanos-Morales, 2008). However, the total loss of externally visible eyes as a fixed character throughout the population was observed for relatively few of these species, namely $T$. sandovali, $T$. spelaeus and T. dali. Similarly, not all of these species present an advanced regression of skin pigmentation, with many of them exhibiting melanic pigments in variable degrees of regression, mainly at dorsum and flanks (e.g., Glaphyropoma spinosum, Silvinichthys bortayro, Ituglanis bambui, I. ramiroi, T. chaberti, T. itacarambiensis) (Bichuette \& Trajano, 2010). Several authors point out that there would be a correlation between the reduction degree of eyes and pigmentation and the time of isolation in the subterranean habitat, and that species with a high degree of regression of eyes and melanic pigmentation have been isolated for a longer time than those with lower or variable degree of reduction in these characters (Langecker, 2000; Bichuette \& Trajano, 2004, 2008).

The elongation of sensorial appendages, basically barbels, has been observed in troglobitic fishes (Hüppop, 2000, among others), including heptapterids as Rhamdia (Weber, 1996) and several trichomycterids (Fernández \& Bichuette, 2002; DoNascimiento et al., 2001; Castellanos-Morales, 2008). Following this trend, T. dali exhibits long barbels, especially the nasal and maxillary ones, both surpassing the head length. Three other species of Trichomycterus exhibits barbels as long or almost as long as those of T. dali: T. longibarbatus, $T$. spelaeus and $T$. sandovali. In the case of T. longibarbatus, no information is given about its habits, but the elongated barbels may indicate that this species depends more on this sensorial appendage to acquire information about their environment. The two last, as T. dali, are restricted to subterranean habitats, where barbels constitute an important source of sensory information about the environment in the absence of light, and its elongation may be involved in sensory compensation as an adaptation to the permanent darkness of the subterranean habitat; however, further studies are needed to corroborate this hypothesis. Another additional feature was proposed by Castellanos-Morales (2008) as possibly related to a hypogean life, the presence of lateral cutaneous folds encircling the body, present on at least three troglomorphic species of the genus, T. santanderensis, $T$. spelaeus and $T$. uisae. In $T$. dali, this feature is present in many, but not all, of the preserved individuals. 
Adipose folds. The presence of dorsal adipose folds in adult T. dali is an intriguing character. The presence of a predorsal adipose fold in adults is unique among the Trichomycterinae. Among other trichomycterids, a similar predorsal adipose fold is only found in the highly-derived sarcoglanidine Sarcoglanis simplex Myers \& Weitzman. However, that structure in Sarcoglanis is much less developed than that in T. dali (compare fig. 1 of Myers \& Weitzman, 1966, with our Fig. 2). In any event, the predorsal fold of $T$. dali necessarily have evolved independently of the condition of Sarcoglanis (cf. de Pinna, 1989, de Pinna \& Starnes, 1990; Costa \& Bockmann, 1994; Costa, 1994), being its presence interpreted as an obvious and distinctive diagnostic feature for the new species herein described.

The well-developed postdorsal adipose fold not supported by procurrent rays in adults of $T$. dali is also unique within Trichomycterus and even among other trichomycterines. A few other trichomycterines also exhibit a small postdorsal adipose fold (e.g., T. stramineus, T. nigromaculatus; Eigenmann, 1918), but that structure in those fishes is never so pronounced as in T. dali. Trichomycterus stawiarski, T. igobi, T. crassicaudatus, and T. lewi exhibit a postdorsal ridge that may resemble the postdorsal adipose fold of T. dali. In these other congeners, however, that ridge is supported by an unusual large number of procurrent caudal rays distributed along most of its extent. In $T$. dali, the procurrent caudal rays are in few number and restricted to the posterior most part of the fold, which is primarily not supported by procurrent rays.

Other trichomycterid taxa also exhibit a postdorsal adipose fold, such as the sarcoglanidines Sarcoglanis simplex and Malacoglanis gelatinosus Myers \& Weitzman, and the Copionodontinae. Given the currently accepted topologies of the trichomycterid phylogenetic relationships (de Pinna, 1992, 1998; Datovo \& Bockmann, 2010), those occurrences are more parsimoniously interpreted as parallelisms.

It is known that, ontogenetically, adipose folds posterior to dorsal fin of juveniles originates the adipose fin present in some adults. Although juveniles of trichomycterid species are not well known because of difficulties in collect these specimens, on at least one species, Copionodon lianae, this ontogenetical development is known to occur (Campanario $\&$ de Pinna, 2000): juveniles C. lianae exhibit a well-developed adipose fold, both pre- and postdorsal, that gradually become smaller as individuals become larger, so that the pre-dorsal fold totally disappears in adults and the post-dorsal fold reaches the appearance of the adipose fin of adults. This is also true for another species of the genus, Copionodon sp. from northeastern Brazil, analyzed by us. In the trichomycterine Ituglanis amazonicus, small juveniles also exhibit pre- and post-dorsal adipose ridges, lost afterward in adult individuals (Lundberg et al., 2004).

Based on this, we could hypothesize the ontogenetic development of the adipose fin in trichomycterids as a shift from the ridge-like adipose fold of juveniles to a fin-like adipose fold (the adipose fin), and its further disappearance on the end of the series. From this hypothetical series, three possible evolutionary paths are represented by adults of different species: the retention in adults of a ridge-like adipose fold, post-dorsal (M. gelatinosus and C. orthiocarinatus) or both pre- and postdorsal (S. simplex and T. dali); the modification to a fin-like adipose fold, i.e., the adipose fin (remaining copionodontines); and the more advanced step, the total loss of pre- and post-dorsal adipose folds, (most trichomycterids). From this, it become clear that the adipose folds of T. dali, $S$. simplex, M. gelatinosus and the Copionodontinae are formed by the retention of the adipose folds of juveniles, in different degrees in each species, representing then a paedomorphic character.

Although this seems to be a reasonable hypothesis, some essential points need to be emphasized. First, the hypothesis is based solely on external morphologic appearance of the adipose fold, and wasn't our intention to accomplish a more detailed analysis of this character, since it would be beyond the scope of this work. Second, very little information is available for juvenile trichomycterids, and as the hypothesis is based on data of only three species (the copionodontines C. lianae and Copionodon sp. and the trichomycterine Ituglanis amazonicus), its weakness must to be considered, as long as new data for other trichomycterid species may completely alter or even refute the hypothesis. Third, even if further studies corroborate this hypothesis, it is clear that the groups so defined must not be considered as natural groups, once that many data suggest other phylogenetic relationships for the species within the groups. Therefore, the degree of retention of adipose folds in adults is better understood as a plastic character that evolved many times within the lineage, and the retention of this fold in adults of different lineages is more likely to represent parallelism. In conclusion, by now this is just a hypothesis that must be further tested before we start to discuss its implications to the understanding of trichomycterid evolution, and the best way to do so is identifying and analyzing juvenile specimens of trichomycterids and building ontogenetical series to track the actual development of the adipose fold.

Anyway, as cited above, in T. dali the adipose folds of adults are very similar morphologically to the adipose folds described for juvenile $C$. lianae, and its presence probably begins early in development, since even in the smallest individuals analyzed $(18.6 \mathrm{~mm}$ SL and $19.6 \mathrm{~mm} \mathrm{SL}$, nonparatype specimens) it was already present, although poorly developed. This evidence give support to the hypothesis of paedomorphic evolution for this character. As all other species of the genus do not exibit this character, and as no other paedomorphic character state could be recognized in T. dali, the retention of the ridge is more probably related to result from neotenic evolution. In cave vertebrate species, neoteny was already reported for troglobitic salamanders, such as the notorious European Proteus anguinus and several North American plethodontids, and fishes, as the North American amblyopsids.

A major ecological feature of subterranean habitats is the 
food scarcity as a limiting factor, and the dependence, in general, on external energy sources, frequently unpredictable and patchy (Langecker, 2000; Culver \& Pipan, 2009). Increased fat layers and large fat deposits have been reported for some hypogean fishes as an adaptation to store energy, in order to cope with periodical starvation (Weber, 1996; Hüppop, 2000; Culver \& White, 2005). We then hypothesize that the well developed adipose fold in $T$. dali, acquired by neoteny, is an adaptation to withstand the energy restrictions and unpredictability of food sources in the subterranean habitat, by accumulating a permanent, reliable storage of energy in the form of adipose reserve. As similar adipose folds have been reported for other, epigean trichomycterids, as discussed above, where similar food restriction may not exist, alternative hypothesis can be related to its evolution on each group.

Comparative material. Ituglanis bambui, MZUSP 79860 , holotype, Brazil: Goiás: São Domingos: Terra Ronca State Park: Angélica Cave. Ituglanis epikarsticus, MZUSP 79869, holotype, Brazil: Goiás: São Domingos: Terra Ronca State Park: São Mateus Cave. Ituglanis passensis: MZUSP 80097, 3, Brazil: Goiás: São Domingos, Passa Três Cave. Ituglanis proops: MZUSP 79576, 15, Brazil: Paraná: Cerro Azul, ribeirão Bonito. Ituglanis ramiroi, MZUSP 79865, holotype, Brazil: Goiás: São Domingos: Terra Ronca State Park: São Bernardo Cave. Ituglanis sp.: MZUSP 53222, 6, Brazil: Goiás: Minaçú, tributary of rio Tocantinzinho. Trichomycetrus bahianus: MZUSP 74655, 10, Brazil: Bahia: Livramento do Brumado, rio Brumado; MZUSP 45887, 7, Brazil: Bahia: Livramento do Brumado, rio Brumado. Trichomycterus itacarambiensis: MZUSP 50548, paratypes, 4, Brazil: Minas Gerais: Itacarambi, Olhos D’Água Cave; MZUSP 50549, paratypes, 2, Brazil: Minas Gerais: Itacarambi, Olhos D’Água Cave; MZUSP 81078, 5, Brazil: Minas Gerais: Itacarambi, Olhos D’Água Cave. Trichomycterus zonatus: MZUSP 68173, 20, Brazil: São Paulo: Cajati, rio do Queimado; MZUSP 23038, 6, Brazil: São Paulo: Caraguatatuba, rio d'Ouro. The comparison with other Trichomycterus species was based on the literature.

\section{Acknowledgements}

Especial thanks are given to A. Datovo da Silva, for his attention, major contributions and valuable advices that enriched this work. We are greatly indebted to the colleagues who joined our speleological expeditions, contributing to the logistics essential for the highly technical cave diving (carried out by E. P. D. Costa-Jr.), L. M. Cordeiro and R. Borghezan, responsible by the expedition to Morro do Jericó. We thank D. Fenolio for the picture of Figure 12; L. B. R. Fernandes and A. M. P. M. Dias for the picture of Figure 4; C. Martins for the help with other pictures; D. Seripieri of the MZUSP library, for her attention and help with literature. Thanks are due to FAPESP, for a long-term support for our studies (in particular, procs. 97/09274-1, 03/00794-5 and 09/15030-7).

\section{Literature cited}

Alencar, A. R. \& W. J. E. M. Costa. 2004. Trichomycterus pauciradiatus, a new catfish species from the upper rio Paraná basin, southeastern Brazil (Siluriformes: Trichomycteridae). Zootaxa, 1269: 43-49.

Almeida, F.F.M. de. 1965. Geologia da Serra da Bodoquena (Mato Grosso), Brasil. Boletim da Divisão de Geologia e Mineralogia, DNPM, 219: 1-96.

Alvarenga, S.M.; A. E. Brasil \&D. M. Del'Arco. 1982. Folha SF21, Campo Grande. 2- Geomorfologia, Projeto RADAM-BRASIL, Rio de Janeiro, 28: 125-184.

Arratia, G. 1990. The South American Trichomycterinae (Teleostei: Siluriformes), a problematic group. Pp: 395-403. In: Peters, G. \& R. Hutterer (Eds.).Vertebrates in the Tropics. Museum Alexander Koening, Bonn.

Arratia, G. 1998. Silvinichthys, a new genus of trichomycterid catfishes from the Argentinian Andes, with redescription of Trichomycterus nigricans. Ichthyological Explorations of Freshwaters, 9: 347-370.

Barr, T. C., Jr., 1968. Cave ecology and the evolution of troglobites. Evolutionary Biology, 2: 35-102.

Bichuette, M. E., M. C. C. de Pinna \& E. Trajano. 2008. A new species of Glaphyropoma: the first subterranean copionodontine catfish and the first occurrence of opercular odontodes in the subfamily (Siluriformes: Trichomycteridae). Neotropical Ichthyology, 6:301-306.

Bichuette, M. E. \& E. Trajano. 2004. Three new subterranean species of Ituglanis from Central Brazil (Siluriformes: Trichomycteridae). Ichthyological Exploration of Freshwaters, 15: 243-256.

Bichuette, M. E. \& E. Trajano. 2005. A new cave species of Rhamdia Bleeker, 1858 (Siluriformes: Heptapteridae) from Serra do Ramalho, northeastern Brazil, with notes on ecology and behavior. Neotropical Ichthyology, 3:587-595.

Bichuette, M. E. \& E. Trajano. 2008. Ituglanis mambai, a new subterranean catfish from a karst area of Central Brazil, rio Tocantins basin (Siluriformes: Trichomycteridae). Neotropical Ichthyology, 6: 9-15.

Bockmann, F. A., L. Casatti \& M. C. C. de Pinna. 2004. A new species of trichomycterid catfish from the Rio Paranapanema basin, southeastern Brazil (Teleostei: Siluriformes), with comments on the phylogeny of the family. Ichthyological Exploration of Freshwaters, 15: 225-242.

Bockmann, F. A. \& R. M. C. Castro. 2010. The blind catfish from the caves of Chapada Diamantina, Bahia, Brazil (Siluriformes: Heptapteridae): description, anatomy, phylogenetic relationships, natural history, and biogeography. Neotropical Ichthyology, 8(4): 673-706.

Boggiani, P. C.; T. R. Fairchild \& A. M. Coimbra.1993. O Grupo Corumbá (Neoproterozóico-Cambriano) na região Central da Serra da Bodoquena, Mato Grosso do Sul (Faixa Paraguai). Revista Brasileira de Geociências, 23: 301-305.

Campanario, C. F. \& M. C. C. de Pinna. 2000. A new species of the primitive trichomycterid subfamily Copionodontinae from northeastern Brazil (Teleostei: Trichomycteridae). Ichthyological Exploration of Freshwaters, 11: 369-375.

Castellanos-Morales, C. A. 2007. Trichomycterus santanderensis: A new species of troglomorphic catfish (Siluriformes: Trichomycteridae) from Colombia. Zootaxa, 1541: 49-55.

Castellanos-Morales, C. A. 2008. Trichomycterus uisae: a new species of hypogean catfish (Siluriformes: Trichomycteridae) from the northeastern Andean Cordillera of Colombia. Neotropical Ichthyology, 6:307-314.

Costa, W. J. E. M. 1994. A new genus and species of Sarcoglanidinae (Siluriformes: Trichomycteridae) from the Araguaia basin, cen- 
tral Brazil, with notes on subfamilial phylogeny. Ichthyological Exploration of Freshwaters, 5: 207-216.

Costa, W. J. E. M. \& F. A. Bockmann. 1993. Un nouveau genre néotropical de la famille des Trichomycteridae (Siluriformes: Loricarioidei). Revue Française d'Aquariologie et Herpetologie, 20: 43-46.

Culver, D. C. 1982. Cave Life: Evolution and Ecology. Cambridge, Harvard University Press, 189p.

Culver, D.C. \& T. Pipan.2009. Biology of caves and other subterranean habitats. Oxford, Oxford University Press, 256 p.

Culver, D. C. \& W. B. White. 2005. Encyclopedia of Caves. Amsterdam, Elsevier Academic Press, 654p.

Datovo, A. \& F. A. Bockmann. 2010. Dorsolateral head muscles of the catfish families Nematogenyidae and Trichomycteridae (Siluriformes: Loricarioidei): comparative anatomy and phylogenetic analysis. Neotropical Ichthyology, 8: 193-246.

DoNascimiento, C., O. Villarreal \& F. Provenzano. 2001. Descripción de una nueva especie de bagre anoftalmo del género Trichomycterus (Siluriformes: Trichomycteridae), de una cueva de la Sierra de Perijá, Venezuela. Boletín de la Sociedad Venezolana de Espelelología, 35: 20-26.

Eschmeyer, W. N. \& J. D. Fong. 2010. Species of Fishes by family/ subfamily. Available from:http://research.calacademy.org/ redirect?url=http://researcharchive.calacademy.org/research/ Ichthyology/catalog/fishcatmain.asp. Accessed May 6, 2010.

Fernández, L. \& M. E. Bichuette. 2002. A new cave dwelling species of Ituglanis from the São Domingos karst, central Brazil (Siluriformes: Trichomycteridae). Ichthyological Exploration of Freshwaters, 13: 273-278.

Fernández, L. \& G. Miranda. 2007. A catfish of the genus Trichomycterus from a thermal stream in southern South America (Teleostei: Siluriformes: Trichomycteridae), with comments on relationships within the genus. Journal of Fish Biology, 71: 1303-1316.

Fernández, L. \& M. C. C. de Pinna. 2005. Phreatic catfish of the genus Silvinichthys from southern South America (Teleostei, Siluriformes, Trichomycteridae). Copeia, 2005: 100-108.

Fernández, L. \& R. P. Vari. 2009. New Species of Trichomycterus from the Andean Cordillera of Argentina (Siluriformes: Trichomycteridae). Copeia, 2009: 195-202.

Galati, E. A. B., V. L. B. Nunes, P. C. Boggiani, M. E. C. Dorval, G. Cristaldo, H. C. Rocha, E. T. Oshiro, R. M. Gonçalves-Andrade \& G. Naufel. 2003. Phlebotomine (Diptera, Psychodidae) in caves of the Serra da Bodoquena, Mato Grosso do Sul state, Brazil. Revista Brasileira de Entomologia 47: 283-296.

Holsinger, J. R. \& D. C. Culver. 1988. The invertebrate cave fauna of Virginia and a part of Eastern Tennessee: Zoogeography and ecology. Brimleyana, 14: 1-162.

Hüppop, K. 2000. How do cave animals cope with the food scarcity in caves? Pp. 159-188. In: Wilkens, H., D. C. Culver and W. F. Humphreys (Eds.). Ecosystems of the World, Vol. 30: Subterranean Ecosystems. Amsterdam, Elsevier, 808p.

Justo, L. J. E. C. 2000. Fosfato da Serra a Bodoquena - Mato Grosso do Sul. In: Programa de Avaliação Geológico-econômica de insumos minerais para agricultura no Brasil, Projeto PIMAGO/TO/MT/MS. Goiânia, CPRM, Relatório Final. 38p.

Langecker, T. G. 2000. The effects of continuous darkness on cave ecology and cavernicolous evolution. Pp. 135-137. In: Wilkens, H., D. C. Culver and W. F. Humphreys (Eds.). Ecosystems of the World, Vol. 30: Subterranean Ecosystems. Amsterdam, Elsevier, 808p.
Lima, S. M. Q. \& W. J. E. M. Costa. 2004. Trichomycterus giganteus (Siluriformes: Loricarioidea: Trichomycteridae): a new catfish from the Rio Guandu basin, southeastern Brazil. Zootaxa, 761: $1-6$.

Lundberg, J. G., T. M. Berra \& J. P. Friel. 2004. First description of small juveniles of the primitive catfish Diplomystes (Siluriformes: Diplomystidae). Icthyological Exploration of Freshwaters, 15: 71-82.

Mattox, G. M. T., M. E. Bichuette, S. Secutti \& E. Trajano. 2008. Surface and subterranean ichthyofauna in the Serra do Ramalho karst area, northeastern Brazil, with updated lists of Brazilian troglobitic and troglophilic fishes. Biota Neotropica, 8: 145152.

Moreira, C. R., M. E. Bichuette, O. T. Oyakawa, M. C. C. de Pinna \& E. Trajano. 2010. Rediscovery and redescription of the unusual subterranean characiform Stygichthys typhlops, with notes on its life history. Journal of Fish Biology, 76: 18151824

Myers, G. S. \& S. H. Weitzman. 1966. Two remarkable new trichomycterid catfishes from the Amazon basin in Brazil and Colombia. Journal of Zoology, London, 149: 277-287.

Nelson, J. S. 2006. Fishes of the World, 4 ed., New York, Wiley, $624 \mathrm{p}$.

de Pinna, M. C. C. 1989. A new sarcoglanidine catfish, phylogeny of its subfamily, and an appraisal of the phyletic status of the Trichomycterinae. American Museum Novitates, 2950: 1-39

de Pinna, M. C. C. 1992. A new subfamily of Trichomycteridae (Teleostei, Siluriformes), lower loricarioid relationships and a discussion on the impact of additional taxa for phylogenetic analysis. Zoological Journal of the Linnean Society, 106: 175229.

de Pinna, M. C. C. 1998. Phylogenetic relationships of Neotropical Siluriformes (Teleostei: Ostariophysi): historical overview and synthesis of hypotheses. Pp. 279-330. In: Malabarba, L. R., R. E. Reis, R. P. Vari, Z. M. S. Lucena \& C. A. S. Lucena (Eds.). Phylogeny and Classification of Neotropical Fishes. Porto Alegre, Edipucrs, 603p.

de Pinna, M. C. C. \& W. C. Starnes, 1990. A new genus of Sarcoglanidinae from the Rio Mamore, Amazon basin, with comments on subfamilial phylogeny (Teleostei, Trichomycteridae). Journal of Zoology, London, 222: 75-88.

Proudlove, G. S. 2010. Biodiversity and distribution of the subterranean fishes of the world. Pp. 41-63. In: Trajano, E., M. E. Bichuette \& B. G. Kapoor (eds.). Biology of Subterranean Fishes. Enfield, Science Publishers, 480p.

Reis, R. E., E. Trajano \& E. Hingst-Zaher. 2006. Shape variation in surface and cave populations of the armoured catfishes Ancistrus (Siluriformes: Loricariidae) from the São Domingos karst area, upper Tocantins River, Brazil. Journal of Fish Biology, 68: 414-429.

Renno, J. F., C. Gazel, G. Miranda, M. Pouilly \& P. Berrebi.2007. Delimiting species by reproductive isolation: the genetic structure of epigean and hypogean Trichomycterus spp. (Teleostei: Siluriformes) in the restricted area of Torotoro (Upper Amazon, Bolivia). Genetica, 131: 325-336.

Romero, A. 2001. Scientists prefer them blind: the history of hypogean fish research. Environmental Biology of Fishes, 62: 43-71.

Romero, A. \& K. M. Paulson. 2001. It's a wonderful hypogean life: a guide to the troglomorphic fishes of the world. Environmental Biology of Fishes, 62: 13-41. 
da Silva, C. C. F., S. L. S. F. da Matta, A. W. S. Hilsdorf, F. Langeani \& A. P. Marceniuk. 2010. Color pattern variation in Trichomycterus iheringi (Eigenmann, 1917) (Siluriformes: Trichomycteridae) from rio Itatinga and rio Claro, São Paulo, Brazil. Neotropical Ichthyology, 8:49-56.

Taylor, W. R. \& G. C. Van Dyke. 1985. Revised procedures for staining and clearing small fishes and other vertebrates for bone and cartilage study. Cybium, 9: 107-119.

Tchernavin, V. V. 1944. A revision of some Trichomycterinae based on material preserved in the British Museum (Natural History). Proceedings of the Natural Society of London, 114: 234-275.

Trajano. E. 1986. Alguns problemas envolvidos na classificação ecológica dos cavernícolas. Espeleo-tema, 15: 25-27.

Trajano, E. 1997. Synopsis of Brazilian troglomorphic fishes. Serie documents - Laboratoire souterrain du C.N.R.S, França, 24: 119-126.

Trajano. E. 2001. Ecology of subterranean catfishes: an overview. Environmental Biology of Fishes, 62: 133-160.

Trajano, E. 2003.Ecology and ethology of subterranean catfishes. Pp. 601-635. In: Arratia, G., B. G. Kapoor, M. Chardon\& R. Diogo (Org.). Catfishes. Ed. 1, Vol. 2 Enfield: Science Publishers, $750 \mathrm{p}$.

Trajano, E. 2010. Source versus sink populations concept applied to the Schiner-Racovitza classification of subterranean organisms, p. 174. In: 20th International Conference on Subterranean Biology, Postojna (book of Abstracts).

Trajano, E. \& M. E. Bichuette. 2004. Diversity of subterranean fishes in Brazil. Pp. 161-163. In: Symposium on World Subterranean Biodiversity - Proceedings. Lyon, França: CNRS Université Claude Bernard Lyon.
Trajano, E. \& M. E. Bichuette. 2010. Subterranean Fishes of Brazil. Pp. 331-355. In: Trajano, E., M. E. Bichuette \&B. G. Kapoor (Eds.). Biology of Subterranean Fishes. Enfield, Science Publishers, 480p.

Trajano, E., S. Secutti \& M. E. Bichuette.2009. Natural history and population data of fishes in caves of the Serra do Ramalho karst area, Middle São Francisco basin, northeastern Brazil. Biota Neotropica, 9: 129-133.

Weber, A. 1996. Cave dwelling catfish populations of the genus Rhamdia (Pimelodidae, Siluroidei, teleostei) in Mexico. Mémoires de Biospéologie, 23: 73-85.

Wosiacki, W. B. 2002. Estudo das relações filogenéticas de Trichomycterinae (Teleostei, Siluriformes, Trichomycteridae) com uma proposta de classificação. Unipublished Ph. D. Dissertation, Universidade de São Paulo, São Paulo. 324p.

Wosiacki, W. B. 2005. A new species of Trichomycterus (Siluriformes: Trichomycteridae) from south Brazil and redescription of T. iheringi (Eigenmann). Zootaxa, 1040: 49-64.

Wosiacki, W. B. \& M. C. C. de Pinna. 2008a. Trichomycterus igobi, a new catfish species from the rio Iguaçu drainage: the largest head in Trichomycteridae (Siluriformes: Trichomycteridae). Neotropical Ichthyology, 6: 17-23.

Wosiacki, W. B. \& M. C. C. de Pinna. 2008b. A New Species of the Neotropical Catfish Genus Trichomycterus (Siluriformes: Trichomycteridae) representing a new body shape for the family. Copeia, 2008: 273-278.

Submitted November 8, 2010

Accepted August 5, 2011

Published September 16, 2011 